\title{
Impact of Government Spending on Private Consumption: Evidence from ECOWAS Countries
}

\author{
Yaya Keho \\ Ecole Nationale Supérieure de Statistique et d'Economie Appliquée (ENSEA) Abidjan, Abidjan, Côte d'Ivoire \\ Email: yayakeho@yahoo.fr
}

How to cite this paper: Keho, Y. (2019) Impact of Government Spending on Private Consumption: Evidence from ECOWAS Countries. Modern Economy, 10, 600-614. https://doi.org/10.4236/me.2019.103041

Received: December 6, 2018

Accepted: March 5, 2019

Published: March 8, 2019

Copyright $\odot 2019$ by author(s) and Scientific Research Publishing Inc. This work is licensed under the Creative Commons Attribution International License (CC BY 4.0).

http://creativecommons.org/licenses/by/4.0/

\section{(c) (i) Open Access}

\begin{abstract}
This study examines the impact of government spending on household consumption for the Economic Community of West African States (ECOWAS). As a modelling strategy, we use the Common Correlated Effect Mean Group (CCEMG) estimator that accounts for both parameter heterogeneity and cross-sectional dependence. The study provides various pieces of evidence through whole-panel and country-level analyses. The panel estimates indicate that government consumption has, on average, a negative effect on private consumption, implying that government and private consumption are substitutes. Country-level results reveal, however, considerable heterogeneity in the degree of substitutability across countries. They show crowding out effects in six countries, crowding in effects in one country and no significant effect in five countries. Therefore, government consumption is not a good instrument to stimulate aggregate demand and economic growth in ECOWAS countries.
\end{abstract}

\section{Keywords}

Government Consumption, Private Consumption, ECOWAS, CCEMG

\section{Introduction}

The impact of government spending on private consumption and economic growth is one of the controversial issues in both theory and empirics. On the theoretical ground, there are different schools of thoughts on the issue. The Keynesian theory of absolute income hypothesis suggests that household current consumption is a function of their current disposable income. Thus, arise in government spending leads to increased output, employment and income, which 
further increases private consumption and generates thus crowding in effect. On the contrary, the standard real business cycle model, under the framework of neoclassical theory, predicts that a rise in government spending reduces private consumption [1] [2] [3]. Generally government can use different sources of financing its spending. The increase in government spending through taxes lowers household permanent income. This negative wealth effect decreases household consumption. Reacting to the increase in taxes, households increase labor supply by working more, which is called substitution effect. Under the standard real business cycle model, the negative wealth effect dominates the substitution effect. As the result, household consumption decreases. This phenomenon is known as crowding out effect or "substitutability hypothesis" between public and private consumption. A number of studies introduced specific modifications in standard real business cycle model to generate crowding in effect [4] [5]. Finally, full ricardian equivalence argues that an increase in government spending, regardless the way of financing, has no impact on household consumption. This holds because households have perfect foresight and knowledge about the economy. Therefore they internalize government's budget constraint into their own lifetime budget constraints [6] [7] [8].

On the empirical ground, there is no clear evidence on the impact of government spending on private consumption. A number of empirical studies found a positive impact of government spending on private consumption [9]-[17]. On the opposite side, other studies found support for the substitutability between government spending and private consumption [6] [18] [19] [20] [21] [22]. Since private consumption constitutes the largest component of gross domestic product and aggregate demand, it is important to understand the impact of government spending on private consumption.

Literature mentioned above points towards the importance of the relationship between government spending and private consumption, however, this area of research is relatively understudied for African countries. Therefore, this study tries to contribute to the empirical literature by investigating the impact of government spending on private consumption for the member countries of the Economic Community of West African States (ECOWAS). We present empirical evidence on the relationship between government spending and private consumption for each of the ECOWAS member countries and for the panel as a whole. By doing this, we provide additional evidence on whether government spending generates "crowding-out" or "crowding-in" effects on the private sector and shed light on the importance of government spending in consumer welfare. To the best of our knowledge, this study is first of its kind to examine the long and short run effects of government spending on private consumption in ECOWAS countries. Secondly, from the methodological perspective, this study uses a more efficient and less restrictive econometric approach which improves the findings on the subject not only for ECOWAS countries but for overall empirical literature on the nexus between government and private consumption. More precisely, we use the Common Correlated Effect Mean Group (CCEMG) 
estimator introduced by [23] which deals with both slope heterogeneity and cross-sectional dependence. Most of existing studies using panel data employed earlier regression methods that impose cross-sectional homogeneity and independence in the error terms. The cross-sectional homogeneity assumption is likely to be violated given the heterogeneity of economies with respect to trade policy, economic conditions and institutional developments. In addition, crosssectional dependence is an important issue when dealing with countries that share geographic proximity. By employing the data of 12 ECOWAS countries, the study provides various pieces of evidence through whole-panel and country-level analyses.

The remainder of the paper is organized as follows. Section 2 outlines the econometric approach that will be used to carry out the empirical analysis. Section 3 reports and discusses the empirical findings of the study. Section 4 concludes the study and provides some policy recommendations.

\section{Econometric Model and Methodology}

The study examines the effect of government expenditure on private consumption using heterogeneous panel estimation techniques 1) to control for omitted variables and endogeneity bias and 2) to detect differences in the effect of government spending on private consumption across countries. In this section, we present the empirical model and discuss some econometric issues.

\subsection{Model Specification}

To test the effect of government consumption on private consumption, the following econometric model was estimated:

$$
\log C_{i t}=\alpha_{i}+\gamma_{i} \log Y_{i t}+\beta_{i} \log G_{i t}+\mu_{i t}
$$

where $C_{i t}$ stand for household consumption, $Y_{i t}$ is income, $G_{i t}$ is government consumption, and $\mu_{i t}$ stands for stochastic disturbance term assumed to follow a normal distribution. The coefficient on income is expected to be positive and lower than one. That on government consumption is ambiguous. The positive (negative) represents complementary (substitution) relationship between government spending and private consumption.

An important feature of our econometric model is that we do not impose a common $\beta$ coefficient on government consumption. Accordingly, the parameter $\beta$ is allowed to vary across countries. We are interested in the average value of $\beta_{p}$ reflecting the long-run effect of government consumption on private consumption.

\subsection{Data and Preliminary Tests}

The study uses annual time series data for 12 member countries of the Economic Community of West African States (ECOWAS), for the period from 1970 to 2016. The countries under study include: Benin, Burkina Faso, Cote d'Ivoire, Gambia, Ghana, Guinea-Bissau, Mali, Niger, Nigeria, Senegal, Sierra Leone and 
Togo. The coverage of countries and time period are dictated by the data availability for at least $\mathrm{T}=30$ observations. It is an unbalanced macro panel data analysis. The variables under investigation are household final consumption expenditure, gross domestic product (GDP) as a proxy for income and government final consumption expenditure.

An important issue in testing econometric relationship between variables is the definition and measurement of the variables. One may choose to work with variables expressed in levels, ratios or per capita terms. Previous studies have either used variables in real or real per capita terms. As robustness check, we estimate two models in this study. The first uses real household consumption, real government consumption and real gross domestic product (GDP) in constant 2010 US dollar. Real data on the variables were obtained from their respective shares in GDP. The second model considers the variables in real per capita terms using population. The dataset comes from the 2018 World Development Indicators of the World Bank. All the variables are transformed into natural logarithm to derive the direct estimation of elasticities.

Table 1 provides descriptive statistics of the variables. It can be observed that there is a wide disparity among ECOWAS countries. For instance, the average real private consumption varies from 19.921 in Gambia to 25.592 in Nigeria. Similarly, the average real government consumption varies from 18.207 in Gambia to 23.525 in Nigeria. The correlation coefficient between private and government consumption suggests the existence of a positive and significant relationship between the two variables in 10 out of the 12 countries and for the whole panel.

Table 1. Descriptive statistics.

\begin{tabular}{ccccccccc}
\hline \multirow{2}{*}{ Country } & $\mathrm{T}$ & \multicolumn{2}{c}{$\mathrm{C}_{\mathrm{t}}$} & \multicolumn{2}{c}{$\mathrm{GDP}_{\mathrm{t}}$} & \multicolumn{2}{c}{$\mathrm{G}_{\mathrm{t}}$} & \multirow{2}{*}{$\rho$} \\
\cline { 3 - 7 } & & Mean & Std. & Mean & Std. & Mean & Std. & \\
\hline Benin & 47 & 21.798 & 0.434 & 22.013 & 0.524 & 19.981 & 0.668 & $0.927^{*}$ \\
Burkina & 47 & 21.768 & 0.544 & 22.080 & 0.637 & 20.293 & 0.977 & $0.941^{*}$ \\
Cote d'Ivoire & 47 & 23.233 & 0.326 & 23.676 & 0.278 & 21.745 & 0.233 & $0.846^{*}$ \\
Gambia & 40 & 19.921 & 0.523 & 20.165 & 0.390 & 18.207 & 0.310 & $-0.355^{*}$ \\
Ghana & 47 & 23.247 & 0.484 & 23.482 & 0.538 & 21.331 & 0.730 & $0.919^{*}$ \\
Guinea-Bissau & 47 & 20.070 & 0.355 & 20.213 & 0.318 & 18.295 & 0.335 & 0.147 \\
Mali & 47 & 22.147 & 0.481 & 22.338 & 0.552 & 20.353 & 0.685 & $0.923^{*}$ \\
Niger & 47 & 21.761 & 0.274 & 22.014 & 0.336 & 19.970 & 0.476 & $0.884^{*}$ \\
Nigeria & 36 & 25.592 & 0.552 & 25.970 & 0.507 & 23.525 & 0.546 & $0.717^{*}$ \\
Senegal & 47 & 22.449 & 0.452 & 22.731 & 0.408 & 20.902 & 0.345 & $0.910^{*}$ \\
Sierra Leone & 47 & 21.151 & 0.366 & 21.307 & 0.299 & 18.922 & 0.354 & $0.882^{*}$ \\
Togo & 47 & 21.183 & 0.510 & 21.497 & 0.326 & 19.535 & 0.266 & $0.411^{*}$ \\
Panel & 546 & 21.982 & 1.450 & 22.244 & 1.498 & 20.215 & 1.474 & $0.955^{*}$ \\
\hline
\end{tabular}

Note: $\rho$ is the correlation coefficient between private and government consumption. ${ }^{*}$ indicates significance at the $5 \%$ level. 
In order to choose the suitable estimator to be used in coefficient estimations, we need to address two econometric key issues. The first issue is to control for the possible cross-sectional dependence across the panel units which results from unobserved common factors. In the earlier studies, it was assumed that errors were cross-sectionally independent. It has been demonstrated that ignoring cross-sectional dependence by employing standard panel estimation methods is likely to produce inconsistent and biased estimates [23]-[28]. Cross-section dependence is an important issue when dealing with countries that are trading partners, closely integrated financially or sharing geographic proximity. This is particularly the case for ECOWAS countries that have important economic inter-relations such as a shock affecting one country influences the other members. This was particularly the case during the Ivorian political crisis over the period 2002-2011, which was felt in Burkina Faso, Mali and Niger. A large number of populations from these three countries live in Cote d'Ivoire and send money to their families to finance consumption. Thus, changes in income in Cote d'Ivoire may affect consumption in these three countries. Therefore, prior to other subsequent analysis we test whether the time series in the panel are cross-section independent.

The econometric literature provides various tests analyzing cross-sectional dependency in panel data [28] [29]. The cross-section dependence test results displayed in Table 2 clearly indicate that the variables are plagued by cross-section dependence. This suggests that there are cross-section connections among ECOWAS countries and that a shock to one of them is likely to affect the others.

The second important issue to test is whether or not the slope coefficients are homogeneous among panel members. In standard panel data estimation methods it is assumed that slope coefficients are identical across countries. If this assumption does not hold, these methods will provide inconsistent and misleading results [30] [31]. Even though ECOWAS countries belong to the same geographic area, they are not identical in terms of economic and demographic conditions. To test for slope homogeneity, we apply a battery of tests. The standard F-test is widely used to test the null hypothesis of slope homogeneity However, the F-test requires that the explanatory variables are strictly exogenous and the error variances are homoscedastic. [32] proposed a slope homogeneity test that relaxes the assumption of homoscedasticity allowing for group-wise heteroscedasticity. In addition to this test, we perform the delta tests of [33] and the

Table 2. Results for cross-sectional dependence tests.

\begin{tabular}{cccc}
\hline Variables & Breusch-Pagan LM & Pesaran scaled LM & Pesaran CD \\
\hline $\mathrm{C}_{\mathrm{t}}$ & $2405.049(0.000)$ & $203.588(0.000)$ & $48.850(0.000)$ \\
$\mathrm{GDP}_{\mathrm{t}}$ & $2452.981(0.000)$ & $207.760(0.000)$ & $49.283(0.000)$ \\
$\mathrm{G}_{\mathrm{t}}$ & $1236.996(0.000)$ & $101.922(0.000)$ & $30.875(0.000)$ \\
Residuals & $255.643(0.000)$ & $16.506(0.000)$ & $1.760(0.078)$
\end{tabular}

Note: ${ }^{*}$ and ${ }^{* *}$ indicate rejection of the null hypothesis of no cross-sectional dependence at the $5 \%$ and $10 \%$ significance levels, respectively. 
Hausman-type comparison of fixed effects and mean group estimates. The results of these tests are presented in Table 3. As can be seen from the table, all the test statistics reject the null hypothesis of slope homogeneity in favor of the alternative hypothesis that heterogeneity exists in the relationship between private and government consumption among ECOWAS countries. This means that inconsistent coefficients will be obtained if the constraint of slope homogeneity is imposed. Therefore, estimation method that accounts for both heterogeneous slopes and cross-sectional dependency should be employed.

\subsection{Common Correlated Effects Mean Group Estimator}

To deal with both cross-section dependence and slope heterogeneity, we use the Common Correlated Effects Mean Group (CCEMG) estimator designed by [23]. This estimator was also found to be robust to omitted variables bias and endogeneity of regressors. The CCEMG estimator assumes the following multifactor error structure:

$$
\begin{gathered}
X_{i t}=\alpha_{1 i}+\phi_{i} f_{t}+\gamma_{i} g_{t}+\eta_{i t} \\
\mu_{i t}=\alpha_{2 i}+\omega_{i} f_{t}+e_{i t}
\end{gathered}
$$

where $f_{t}$ and $g_{t}$ are unobservable time variant common factors with country-specific factor loadings $\phi_{i}$ and $\gamma_{i}$ and $\eta_{i t}$ and $e_{i t}$ are individual country-specific idiosyncratic errors assumed to be distributed independently of the common factors and across panel units. The error term, $\mu_{i t}$ is allowed to be correlated with the regressors $X_{i t}$ through the presence of the factors $f_{t}$ and $g_{t}$. This implies that if the factor loadings $\phi_{i}$ and $\omega_{i}$ are non-zero, estimating Equation (1) without accounting for this correlation will produce biased and inconsistent estimates of long run effects. The CCEMG estimator solves the issue of cross-section dependence by augmenting the regression equation with the cross-sectional averages of the dependent variable as well as the observed regressors:

$$
\log C_{i t}=\alpha_{i}+\gamma_{i} \log Y_{i t}+\beta_{i} \log G_{i t}+d_{1 i} \overline{\log C}_{t}+d_{2 i} \overline{\log Y}_{t}+d_{3 i} \overline{\log G}_{t}+e_{i t}
$$

Equation (4) is estimated by OLS for each cross-section. The consistent mean group estimator is derived as the simple average of the group-specific estimates.

To test whether there is a long-run relationship between private consumption, income and government expenditure, we perform the residual-based panel

Table 3. Results of homogeneity tests.

\begin{tabular}{ccc}
\hline Test & Statistic & Prob. \\
\hline Hausman test & $142.062^{*}$ & 0.000 \\
Swamy test & $563.80^{\star}$ & 0.000 \\
Delta & $136.074^{*}$ & 0.000 \\
Delta adjusted & $182.307^{*}$ & 0.000 \\
\hline
\end{tabular}

Note: The Hausman test compares Fixed Effects model with Mean Group estimator. ${ }^{\star}$ indicates rejection of the null hypothesis at $5 \%$ significance level. 
cointegration test for the CCEMG model. We apply the Cross-sectionally Augmented Dickey-Fuller (CADF) unit root test proposed by [31] to the residuals obtained from the CCEMG estimation. In presence of cointegration among the variables, we estimate the short run relationship through a panel error correction model given by:

$$
\Delta \log C_{i t}=a_{i}+\theta_{i} \Delta \log Y_{i t}+\varphi_{i} \Delta \log G_{i t}+\lambda_{i} e c t_{i t-1}+v_{i t}
$$

where $\Delta$ is the first difference operator and $e c t_{i t-1}$ is the lagged error correction term computed from the long-run cointegrating relationship of Equation (1), in which $e c t_{i t-1}=\log C_{i t-1}-\alpha_{i}-\gamma_{i} \log Y_{i t-1}-\beta_{i} \log G_{i t-1}$. Equation (5) is estimated using CCEMG estimator.

\section{Empirical Results and Discussion}

Before carrying out the empirical analysis, we test for the order of integration of the variables by means of unit root tests. This step is necessary to make sure that we do not run spurious regressions. We first apply the well-known IPS test developed by [34], which is less restrictive and more powerful compared to the other first generation panel unit root tests. The IPS test allows heterogeneity in the autoregressive coefficient. However, it assumes that errors are independent across countries. Given the above results, we employ the Cross-sectional Augmented Dickey-Fuller (CADF) test proposed by [31], which deals with both heterogeneity and cross-section dependence. The results of these tests are reported in Table 4. They indicate that the null hypothesis of unit root cannot be rejected for all variables. However, when applied to the first differences of the variables, the null hypothesis of unit root is rejected at the $5 \%$ significant level. Thus, we can regard the variables as being integrated of order one, which suggests that there might be a long-run relationship among them.

The existence of cross-sectional dependency and slope heterogeneity among countries make the CCEMG estimator suitable for estimating the long and short run relationships between government and private consumption. To enable comparison of the results, we also run the Mean Group (MG) estimator which assumes independent errors. The results for the whole panel are depicted in Table 5. For each model we test the residuals for non-stationarity using heterogeneous panel unit root tests. As the CD test statistics clearly show, there is a high

Table 4. Panel unit root test results.

\begin{tabular}{ccccc}
\hline & \multicolumn{2}{c}{ Level } & \multicolumn{2}{c}{ First difference } \\
\cline { 2 - 5 } & IPS test & CADF test & IPS test & CADF test \\
\hline Cons & $6.012(1.000)$ & $0.367(0.643)$ & $-24.235^{*}(0.000)$ & $-6.534^{\star}(0.000)$ \\
G & $1.587(0.934)$ & $-2.043^{*}(0.021)$ & $-22.517^{\star}(0.000)$ & $-5.941^{\star}(0.000)$ \\
GDP & $9.077(1.000)$ & $1.193(0.884)$ & $-19.006^{*}(0.000)$ & $-6.046^{\star}(0.000)$ \\
\hline
\end{tabular}

Notes: Tests are conducted for model with intercept. p-values are in parentheses. Optimal lag length was determined using AIC with a maximum of $5 .{ }^{*}$ denotes rejection of the null hypothesis of unit root at the $5 \%$ significant level. 
Table 5. Long-run relationship between private and government consumption.

\begin{tabular}{ccccc}
\hline \multicolumn{5}{c}{ Dependent variable: log of private consumption } \\
& \multicolumn{2}{c}{ Model 1 } & \multicolumn{2}{c}{ Model 2 } \\
\cline { 2 - 5 } & CCEMG & MG & CCEMG & MG \\
\hline G & $-0.096^{* *}(-1.87)$ & $-0.110^{*}(-2.13)$ & $-0.123^{*}(-2.73)$ & $-0.125^{*}(-2.49)$ \\
GDP & $0.942^{*}(11.74)$ & $1.123^{*}(19.2)$ & $0.733^{*}(7.91)$ & $0.782^{*}(9.20)$ \\
Intercept & $0.030(0.04)$ & $-0.787(-0.87)$ & $0.503(0.43)$ & $1.695^{*}(3.15)$ \\
RMSE & 0.060 & 0.083 & 0.061 & 0.083 \\
CD test & $-1.024[0.305]$ & $3.390^{*}[0.001]$ & $-1.213[0.225]$ & $3.36^{*}[0.001]$ \\
IPS & $-12.492^{*}[0.000]$ & $-7.220^{*}[0.000]$ & $-12.227^{*}[0.000]$ & $-7.585^{*}[0.000]$ \\
CADF & $-5.300^{*}[0.000]$ & $-3.583^{*}[0.000]$ & $-6.168^{*}[0.000]$ & $-3.392^{*}[0.000]$ \\
\hline
\end{tabular}

Note: In model 1 the variables are in real terms while in model 2 they are in real per capita terms. CCEMG is the Common Correlated Effects Mean Group estimator and MG refers to the Mean Group estimator. Figures in parentheses are t-statistics and those in brackets are p-values. The CD test statistics are Pesaran [44] CD test for cross-section dependence on the residuals of CCEMG and MG estimates. ${ }^{*}$ and ${ }^{* *}$ indicate significance at the $5 \%$ and $10 \%$ levels, respectively.

degree of cross-section dependence for the MG estimates, but no evidence of cross-section dependence for the CCEMG estimates. In addition the CCEMG estimator shows a lower root mean square error. For this reason, we rely on the CCEMG estimates for inference. From the CCEMG results, it can be seen that private consumption responds negatively to changes in government consumption. A one percent growth in government consumption expenditure leads to a 0.10 percent decline in private consumption. This is an indication of crowing out effect in the long run. This crowding out of private consumption could be explained by the existence of a negative wealth effect induced by increased government expenditure. Thus short term negative wealth effect offsets substitution effect. The negative relationship between government and private consumption is consistent with [22] who found that government and private consumption are substitutes in 24 African countries.

The results further show that there is a positive and significant relationship between consumption and current income. An increase of one percent in income causes household consumption expenditure to rise by 0.9 percent, by keeping other things constant. The coefficient on real total income is greater than that on government consumption, indicating that household consumption strongly depends on current income. This finding is consistent with the Keynesian Absolute Income Hypothesis and other empirical studies [35]-[41], but contradicts with [42] and [43] who found no significant effect of gross domestic product on private consumption expenditure. The IPS and CADF test results suggest rejection of the null hypothesis of unit root in the residuals. Therefore, private consumption, government consumption and income have a long run relationship over the period under study.

The mere fact that the results for the whole panel reveal a negative and signif- 
icant relationship between government and private consumption does not necessarily imply that the crowing-out effect holds in each individual country. To make sure that this result is not driven by a few countries, we look at the country-level CCEMG estimates. The results are reported in Table 6. As expected, they show considerable heterogeneity in the impact of government consumption and income on private consumption. The elasticity of government consumption ranges from -0.389 (Gambia) to 0.234 (Cote d'Ivoire). It is worth mentioning that out of the 12 countries, government consumption has significant negative effect on private consumption in six countries (Benin, Burkina Faso, Gambia, Ghana, Mali and Niger), significant positive effect in Cote d'Ivoire, and no significant effect in five countries (Guinea-Bissau, Nigeria, Senegal, Sierra Leone and Togo). Our finding of no significant relationship between government and private consumption goes with the Barro-Ricardian equivalence hypothesis. The result for Nigeria contradicts with [14] who found a positive and significant effect of government expenditure on private consumption. Thus, Cote d'Ivoire is the only country of ECOWAS for which government expenditure has a complementary relationship with private consumption. This finding indicates that substitution effect is greater than negative wealth effect in Cote d'Ivoire. Therefore, government expenditure can be used to induce household consumption growth in Cote d'Ivoire. In other words, the achievement of economic wellbeing through government expenditure could be possible in Cote d'Ivoire. The finding

Table 6. Country-level CCEMG results.

\begin{tabular}{|c|c|c|c|c|}
\hline \multicolumn{5}{|c|}{ Dependent variable is log of private consumption } \\
\hline \multirow{2}{*}{ Country } & \multicolumn{2}{|c|}{ Model 1} & \multicolumn{2}{|c|}{ Model 2} \\
\hline & G & GDP & G & GDP \\
\hline Benin & $-0.109^{*}(-3.21)$ & $0.929 *(10.59)$ & $-0.182^{\star}(-4.69)$ & $0.581^{*}(3.00)$ \\
\hline Burkina Faso & $-0.197^{\star}(-5.46)$ & $1.250^{*}(15.65)$ & $-0.263^{\star}(-6.54)$ & $1.230^{*}(8.59)$ \\
\hline Cote d'Ivoire & $0.234^{\star}(3.51)$ & $0.660^{*}(7.32)$ & $0.200^{\star}(3.61)$ & $0.449^{*}(5.83)$ \\
\hline Gambia & $-0.389^{*}(-6.02)$ & $1.556^{\star}(7.07)$ & $-0.335^{\star}(-6.75)$ & $0.335(0.65)$ \\
\hline Ghana & $-0.238^{\star}(-5.65)$ & $1.222^{*}(12.75)$ & $-0.220^{\star}(-5.08)$ & $1.135^{\star}(8.84)$ \\
\hline Guinea-Bissau & $-0.037(-0.80)$ & $1.047^{\star}(8.76)$ & $-0.085^{\star *}(-1.96)$ & $0.947^{*}(7.26)$ \\
\hline Mali & $-0.288^{\star}(-4.00)$ & $0.818^{\star}(6.72)$ & $-0.216^{*}(-3.19)$ & $0.682^{*}(4.98)$ \\
\hline Niger & $-0.214^{*}(-5.11)$ & $0.845^{\star}(12.38)$ & $-0.226^{*}(-3.98)$ & $1.174^{*}(19.95)$ \\
\hline Nigeria & $0.028(0.59)$ & $0.621^{*}(3.03)$ & $0.018(0.37)$ & $0.711^{*}(3.12)$ \\
\hline Senegal & $0.074(1.07)$ & $0.703^{\star}(6.99)$ & $-0.087(-1.59)$ & $0.333^{*}(2.54)$ \\
\hline Sierra Leone & $0.062(0.78)$ & $0.818^{\star}(7.97)$ & $0.088(1.16)$ & $0.733^{*}(7.46)$ \\
\hline Togo & $-0.082(-0.81)$ & $0.836^{\star}(4.45)$ & $-0.176(-1.90)$ & $0.485^{\star *}(1.92)$ \\
\hline
\end{tabular}

Note: In model 1 the variables are in real terms while in model 2 they are in real per capita terms. Figures in parentheses are t-statistics. ${ }^{*}$ and ${ }^{* *}$ indicate significance at the $5 \%$ and $10 \%$ levels, respectively. 
of a positive response of private consumption expenditure to government expenditure supports the Keynesian effects of fiscal policy on private consumption. The elasticity of consumption with respect to current income is positive and significant in all countries, confirming the Keynesian absolute income hypothesis. This means that increase in economic growth has significant impact on private consumption in ECOWAS member countries. This finding is in contrast to the work of [43] which reports an insignificant relationship between income and private consumption expenditure in the case of Nigeria. The country-level results also show that the elasticity of income is greater than that of government consumption (Table 6).

Since the variables under study are cointegrated, we have estimated the error correction model to obtain short run dynamic relationship and results are reported in Table 7. The point estimates on the error correction term are negative and statistically significant in all countries and for the whole-panel. This provides evidence in support of the existence of a long-run relationship between the three variables. For the panel, the coefficient on government consumption is negatively signed and statistically significant. The implication is that a growth in government consumption is likely to result in a decrease in household consumption in the short run. The crowding out effect is confirmed in the short run at the panel level. The coefficient of income is positive and significant. A one percent rise in income increases private consumption by approximately 0.8 percent on average. The results are similar to those in the long run.

Table 7. Short run estimates.

\begin{tabular}{|c|c|c|c|c|c|c|}
\hline \multicolumn{7}{|c|}{ Dependent variable is private consumption growth rate } \\
\hline \multirow{2}{*}{ Country } & \multicolumn{3}{|c|}{ Model 1} & \multicolumn{3}{|c|}{ Model 2} \\
\hline & G & GDP & ECT & G & GDP & ECT \\
\hline Benin & $-0.106^{*}(-2.34)$ & $0.907^{\star}(4.19)$ & $-0.586^{*}(-3.94)$ & $-0.162^{\star}(-2.97)$ & $0.872^{\star}(3.87)$ & $-0.438^{*}(-3.20)$ \\
\hline Burkina Faso & $-0.176^{\star}(-3.70)$ & $1.156^{*}(4.64)$ & $-0.341^{*}(-2.57)$ & $-0.196^{\star}(-3.97)$ & $1.166^{\star}(4.57)$ & $-0.334^{\star}(-2.42)$ \\
\hline Cote d'Ivoire & $0.102^{\star *}(1.81)$ & $0.775^{*}(4.76)$ & $-0.482^{\star}(-3.81)$ & $0.156^{\star}(2.76)$ & $0.663^{\star}(4.05)$ & $-0.637^{\star}(-4.15)$ \\
\hline Gambia & $-0.374^{\star}(-6.88)$ & $0.919^{*}(2.13)$ & $-0.430^{*}(-2.36)$ & $-0.318^{*}(-5.78)$ & $0.755^{\star *}(1.81)$ & $-0.482^{*}(-3.02)$ \\
\hline Ghana & $-0.251^{\star}(-4.84)$ & $1.436^{*}(6.32)$ & $-0.884^{*}(-5.18)$ & $-0.250^{*}(-4.82)$ & $1.435^{\star}(6.28)$ & $-0.825^{\star}(-4.67)$ \\
\hline Guinea-Bissau & $-0.007(-0.13)$ & $0.841^{*}(6.57)$ & $-0.719^{*}(-5.08)$ & $-0.038(-0.72)$ & $0.792^{*}(6.09)$ & $-0.707^{\star}(-4.88)$ \\
\hline Mali & $-0.142^{\star}(-2.42)$ & $0.076(0.33)$ & $-0.433^{*}(-2.86)$ & $-0.130^{*}(-2.45)$ & $0.088(0.43)$ & $-0.544^{\star}(-3.88)$ \\
\hline Niger & $-0.221^{\star}(-4.33)$ & $0.763^{*}(5.71)$ & $-0.864^{\star}(-5.21)$ & $-0.169^{*}(-3.12)$ & $0.837^{*}(5.63)$ & $-0.565^{\star}(-4.16)$ \\
\hline Nigeria & $0.063(1.02)$ & $0.494(1.57)$ & $-1.007^{\star}(-4.86)$ & $0.088(1.38)$ & $0.465(1.43)$ & $-0.991^{\star}(-4.68)$ \\
\hline Senegal & $0.033(0.48)$ & $0.589^{*}(5.13)$ & $-0.445^{\star}(-3.65)$ & $0.041(0.57)$ & $0.514^{*}(3.97)$ & $-0.514^{*}(-2.76)$ \\
\hline Sierra Leone & $-0.035(-0.59)$ & $1.039^{*}(6.85)$ & $-0.647^{\star}(-4.82)$ & $-0.018(-0.28)$ & $0.992^{\star}(5.90)$ & $-0.669^{*}(-4.62)$ \\
\hline Togo & $0.069(0.80)$ & $0.942^{*}(4.00)$ & $-1.280^{\star}(-8.43)$ & $0.030(0.31)$ & $0.859^{\star}(3.31)$ & $-1.178^{\star}(-7.27)$ \\
\hline Panel & $-0.087^{\star}(-2.02)$ & $0.828^{*}(8.38)$ & $-0.677^{\star}(-8.26)$ & $-0.080^{\star *}(-1.92)$ & $0.786^{\star}(7.92)$ & $-0.645^{\star}(-8.86)$ \\
\hline
\end{tabular}

Note: In model 1 the variables are in real terms while in model 2 they are in real per capita terms. Figures in parentheses are $\mathrm{t}$-statistics. ${ }^{\star}$ and ${ }^{\star}$ indicate significance at the $5 \%$ and $10 \%$ levels, respectively. 
The country-level estimates show a crowding out effect of government consumption on private consumption in Benin, Burkina Faso, Gambia, Ghana, Mali and Niger, and no significant effect in Guinea-Bissau, Nigeria, Senegal, Sierra Leone and Togo. However, there is a crowding in effect of government consumption on private consumption in the case of Cote d'Ivoire. As can be seen, a one percent increase in government consumption leads to an increase in private consumption by 0.10 percent. Hence, Keynesian hypothesis of positive relationship between government and private consumption holds only in Cote d'Ivoire. Therefore, private consumption cannot be held responsible for any crowding-out effect that government spending might have on aggregate demand in Cote d'Ivoire. The estimated coefficient of the income variable is positive and significant in all countries except Mali and Nigeria.

\section{Conclusions and Recommendations}

In this study, we examined the effect of government consumption on household final consumption expenditure for 12ECOWAS countries over the period from 1970 to 2016 . We employed a panel estimation technique that is specifically designed to deal with the key econometric problems plaguing previous studies, namely cross-section dependence and slope heterogeneity. Our empirical strategy deals with these issues using the Common Correlated Effects Mean Group estimator developed by [23]. The whole-panel results indicate that government consumption has, on average, a negative effect on private consumption. This suggests that the crowding out effect holds in ECOWAS as a whole. The estimated negative effect is consistent with neoclassical theoretical framework. However, the country-level evidence shows large cross-country variations in the effect of government consumption on household consumption, probably due to the country-specific economic conditions. The effect is negative in six countries (Benin, Burkina Faso, Gambia, Ghana, Mali and Niger), positive in Cote d'Ivoire, and not significant in five countries (Guinea-Bissau, Nigeria, Senegal, Sierra Leone and Togo). Therefore, government consumption is not a very good instrument to induce aggregate demand and boost economy in ECOWAS area. The only exception is Cote d'Ivoire for which government and private consumption were found to be complements. For this country government consumption can be used to stimulate household consumption. The results of the study clearly show that the nexus between government and private consumption is country-specific. We also found that consumption depends positively on current income with strong cross-country heterogeneity. Although our primary interest does not focus on consumption-income linkage, this evidence confirms the Keynesian absolute income hypothesis and shows that current income is the major driver of private consumption growth both in the long and short run.

The results of this study call for some plausible reasons behind the nature of the relationship between government and private consumption. Why countries show different patterns in this nexus? The study has used aggregate data and as we know individual components of government spending might have different 
relationships with household consumption. In fact, various components of government spending would be valued differently by households and would affect their consumption decision differently. For instance, if government spends more on education and health, households would then have to spend less in those items. On the contrary, if government spending is intending to improve public transport system, households would use public transport more frequently and spend more on transportation. Therefore, the composition of government spending may determine the differential and heterogeneous effects on household consumption across countries. Thus, there is scope for further research by disaggregating government consumption into different components. Another plausible explanation of our results could lie in the way used by governments to finance their spending. Finally, our estimation method has assumed the effect of government spending on private consumption to be the same regardless the level of household consumption. This effect could be different for households with different consumption levels. Thus, as another future avenue of research, we suggest analyzing the asymmetric effects of government spending along the distribution of private consumption. We leave all these challenging avenues for future researches.

\section{Conflicts of Interest}

The author declares no conflicts of interest regarding the publication of this paper.

\section{References}

[1] Aiyagari, S., Rao, L., Christiano, J. and Eichenbaum, M. (1992) The Output, Employment, and Interest Rates Effects of Government Consumption. Journal of Monetary Economics, 30, 73-86. https://doi.org/10.1016/0304-3932(92)90045-4

[2] Baxter, M. and King, R.G. (1993) Fiscal Policy in General Equilibrium. American Economic Review, 83, 315-334.

[3] Christiano, L. and Eichenbaum, M. (1992) Current Real-Business-Cycle Theories and Aggregate Labormarket Fluctuations. American Economic Review, 82, 430-450.

[4] Linnemann, L. (2006) The Effect of Government Spending on Private Consumption: A Puzzle? Journal of Money, Credit and Banking, 38, 1715-1735. https://doi.org/10.1353/mcb.2006.0094

[5] Bouakez, H. and Rebei, N. (2007) Why Does Private Consumption Rise after a Government Spending Shock? The Canadian Journal of Economics, 40, 954-979. https://doi.org/10.1111/j.1365-2966.2007.00438.x

[6] Kormendi, R.C. (1983) Government Debt, Government Spending and Private Sector Behaviour. American Economic Review, 73, 994-1010.

[7] Modigliani, F. and Sterling, A. (1986) Government Debt, Government Spending and Private Sector Behavior: Comment. American Economic Review, 76, 1168 1179.

[8] Cardia, E. (1997) Replicating Ricardian Equivalence Test with Simulated Series. American Economic Review, 87, 65-79.

[9] Karras, G. (1994) Government Spending and Private Consumption: Some Interna- 
tional Evidence. Journal of Money, Credit and Banking, 26, 9-22.

https://doi.org/10.2307/2078031

[10] Blanchard, O.J. and Perotti, R. (2002) An Empirical Characterization of the Dynamic Effects of Changes in Government Spending and Taxes on Output. Quarterly Journal of Economics, 117, 1329-1368. https://doi.org/10.1162/003355302320935043

[11] Nieh, C.-C. and Ho, T.-W. (2006) Does the Expansionary Government Spending Crowd out the Private Consumption? Cointegration Analysis in Panel Data. Quarterly Review of Economics and Finance, 46, 133-148. https://doi.org/10.1016/j.qref.2004.11.004

[12] Galí, J., López-Salido, J.D. and Vallés, J. (2007) Understanding the Effects of Government Spending on Consumption. Journal of the European Economic Association, 5, 227-270. https://doi.org/10.1162/JEEA.2007.5.1.227

[13] Tagkalakis, A. (2008) The Effects of Fiscal Policy on Consumption in Recessions and Expansions. Journal of Public Economics, 92, 1486-1508. https://doi.org/10.1016/j.jpubeco.2007.11.007

[14] Onodje, A.M. (2009) An Insight into the Behaviour of Nigeria's Private Consumer Spending. Economic and Policy Review, 15, 8-15.

[15] D’Alessandro, A. (2010) How Can Government Spending Affect Private Consumption? A Panel Cointegration Approach. European Journal of Economics, Finance and Administrative Sciences, 18, 1450-2275.

[16] Chen, Y., Luan, F. and Huang, W. (2014) The Effect of Government Expenditure on Private Consumption: Evidence from China. Journal of Global Economics, 2, 120. https://doi.org/10.4172/2375-4389.1000120

[17] Khalid, K., Fei, C., Muhammad, A.K. and Badar, N.A. (2015) Impact of Government Spending on Private Consumption Using ARDL Approach. Asian Economic and Financial Review, 5, 239-248.

https://doi.org/10.18488/journal.aefr/2015.5.2/102.2.239.248

[18] Aschauer, D.A. (1985) Fiscal Policy and Aggregate Demand. American Economic Review, 75, 117-127.

[19] Ahmed, S. (1986) Temporary and Permanent Government Spending in an Open Economy: Some Evidence for the United Kingdom. Journal of Monetary Economics, 17, 197-224. https://doi.org/10.1016/0304-3932(86)90028-0

[20] Ho, T.-W. (2001) The Government Spending and Private Consumption: A Panel Cointegration Analysis. International Review of Economics and Finance, 10, 95-108. https://doi.org/10.1016/S1059-0560(00)00073-3

[21] Auteri, M. and Costantini, M. (2010) A Panel Cointegration Approach to Estimating Substitution Elasticities in Consumption. Economic Modelling, 27, 782-787. https://doi.org/10.1016/j.econmod.2010.01.021

[22] Dawood, T. and Francois, J.N. (2018) Substitution between Private and Government Consumption in African Countries. Economic Modelling, 73, 129-139. https://doi.org/10.1016/j.econmod.2018.03.012

[23] Pesaran, M.H. (2006) Estimation and Inference in Large Heterogeneous Panels with a Multifactor Error Structure. Econometrica, 74, 967-1012. https://doi.org/10.1111/j.1468-0262.2006.00692.x

[24] Driscoll, J.C. and Kraay, A.C. (1998) Consistent Covariance Matrix Estimation with Spatially Dependent Panel Data. Review of Economics and Statistics, 80, 549-560. https://doi.org/10.1162/003465398557825 
[25] Eberhardt, M. and Teal, F. (2011) Econometrics for Grumblers: A New Look at the Literature on Cross-Country Growth Empirics. Journal of Economic Surveys, 25, 109-155. https://doi.org/10.1111/j.1467-6419.2010.00624.x

[26] Kapetanios, G., Pesaran, M. and Yamagata, T. (2011) Panels with Non-Stationary Multifactor Error Structures. Journal of Econometrics, 160, 326-348. https://doi.org/10.1016/j.jeconom.2010.10.001

[27] Sarafidis, V. and Wansbeek, T. (2012) Cross-Sectional Dependence in Panel Data Analysis. Econometric Reviews, 31, 483-531. https://doi.org/10.1080/07474938.2011.611458

[28] De Hoyos, R.E. and Sarafidis, Y. (2006) Testing for Cross-Sectional Dependence in Panel Data Models. The Stata Journal, 6, 482-496. https://doi.org/10.1177/1536867X0600600403

[29] Chudik, A. and Pesaran, M.H. (2015) Common Correlated Effects Estimation of Heterogeneous Dynamic Panel Data Models with Weakly Exogenous Regressors. Journal of Econometrics, 188, 393-420. https://doi.org/10.1016/j.jeconom.2015.03.007

[30] Pesaran, M.H. and Smith, R.P. (1995) Estimating Long-Run Relationship from Dynamic Heterogenous Panels. Journal of Econometrics, 68, 79-113. https://doi.org/10.1016/0304-4076(94)01644-F

[31] Pesaran, M.H. (2007) A Simple Panel Unit Root Test in the Presence of Cross Section Dependence. Journal of Applied Econometrics, 22, 265-312. https://doi.org/10.1002/jae.951

[32] Swamy, P.A.B. (1970) Efficient Inference in a Random Coefficient Regression Model. Econometrica, 38, 311-323. https://doi.org/10.2307/1913012

[33] Pesaran, M.H. and Yamagata, T. (2008) Testing Slope Homogeneity in Large Panels. Journal of Econometrics, 142, 50-93. https://doi.org/10.1016/j.jeconom.2007.05.010

[34] Im, K.S., Peseran, M.H. and Shin, Y. (2003) Testing for Unit Roots in Heterogeneous Panels. Journal of Econometrics, 115, 53-74. https://doi.org/10.1016/S0304-4076(03)00092-7

[35] Forgha, N.G. (2008) Econometric Models of Consumption and Savings Functions in Cameroon: An Error Correction Methodology. International Review of Business Research Papers, 4, 291-308.

[36] Bonsu, C.O. and Muzindutsi, P.-F. (2017) Macroeconomic Determinants of Household Consumption Expenditure in Ghana: A Multivariate Cointegration Approach. International Journal of Economics and Financial Issues, 7, 737-745.

[37] Akekere, J. and Yousuo, P.O.J. (2012) Empirical Analysis of Change in Income on Private Consumption Expenditure in Nigeria from 1981-2010. International Journal of Academic Research in Business and Social Sciences, 2, 188-197.

[38] Alice, O.C. (2013) An Estimation of the Consumption Function for Kenya Using Keynes' Absolute Income Hypothesis for the Period 1992-2011. Journal of Emerging Trends in Economics and Management Sciences, 4, 103-105.

[39] Ofwona, A.C. (2013) An Estimation of the Consumption Function for Kenya Using Keynes' Absolute Income Hypothesis for the Period 1992-2011. Journal of Emerging Trends in Economics and Management Sciences, 4, 103-105.

[40] Odionye, C.J., Ugwuebe, S.U. and Ibeleme, S.O. (2015) The Effect of Financial Wealth on Private Consumption: Evidence from Nigeria. British Journal of Economics, Management \& Trade, 6, 300-307.

[41] Sekantsi, L.P. (2016) Determinants of Real Private Consumption Expenditure in 
Lesotho. European Journal of Economics and Management, 3, 72-89.

[42] Chioma, N.J. (2009) Causal Relationship between Gross Domestic Product and Personal Consumption Expenditure of Nigeria. African Journal of Mathematics and Computer Science Research, 2, 179-183.

[43] Nwabueze, J.C. (2009) Causal Relationship between Gross Domestic and Personal Consumption Expenditure of Nigeria. African Journal of Mathematics and Computer Science Research, 2, 179-183.

[44] Pesaran, M.H. (2004) General Diagnostic Tests for Cross Section Dependence in Panels. CESifo Working Paper Series No. 1229, IZA Discussion Paper No. 1240. 